Військово-навчальні заклади зобов'язані «стройовому» навчанню бадьорим виглядом своїх вихованців, їх виправкою, ознайомленням їх із зовнішніми формами військової пристойності й майже повною відсутністю юнаків 3 кіфозними, лордозними або сколіозними скривленнями. Досягається це простими вправами, нешкідливість яких для дітей гарантується тим, що вони проводяться їхніми безпосередніми офіцерами-вихователями, які відповідають за життя та здоров'я своїх вихованців.

\title{
Література
}

1. Бутовский А. Д. Собрание сочинений: в 4 т. / А. Д. Бутовский. - К. : Олимп. л-ра, 2009. - Т. 3 - 358 с. 2. Бутовский А. Д. Телесные упражнения и внеклассные занятия в кадетских корпусах / А. Д. Бутовский. - М., 1898. 3. Греков Ф. В. Краткий исторический очерк военно-учебных заведений 1700-1910 / Ф. В. Греков. M., 1910.

УДК 37 (013)

Валерія Устименко

\section{УПЛИВ СОЦІЛЬНО-ПОЛІТИЧНИХ ЧИННИКІВ НА ФОРМУВАННЯ БАГАТОМОВНОСТІ В КАНАДІ}

Устименко В. В. Уплив соціально-політичних чинників на формування багатомовності в Канаді.

У статті розглянуто поняття двомовності та багатомовності як важливі аспекти соціально-політичного життя в Канаді. Основну увагу приділено причинам виникнення та етапам розвитку багатомовності.

Ключові слова: Канада, офіційна мова, офіційна двомовність, білінгвізм, багатомовність, мультилінгвізм.

Устименко В. В. Влияние социально-политических факторов на формирование многоязычия в Канаде.

В статье рассматриваются понятия двуязычия и многоязычия как важные аспекты социально-политической жизни в Канаде. Основное внимание уделяется причинам возникновения и этапам развития многоязычия.

Ключевые слова: Канада, официальный язык, официальное двуязычие, билингвизм, многоязычие, мультилингвизм.

Ustimenko V. V. Influence of socio-political factors on multilingual formation in Canada.

The article examines the notions of bilingualism and multilingualism as important aspects of modern socio-political life in Canada considering globalization and mankind transition to information society; the most favorable conditions for bilingualism and multilingualism emergence are defined. The focus is on reasons of emergence and stages of multilingualism development in Canada.

Key words: Canada, official language, official bilingualism, bilingualism, multilingualism.

Політичні та суспільні зміни, які відбуваються в сучасному світі, 3 притаманними йому інтеграцією та глобалізацією, як всесвітньою багаторівневою мережею найрізноманітніших зв'язків та високим рівнем розвитку технічних 
засобів комунікації, зумовлюють необхідність знання однієї або навіть кількох іноземних мов.

Зміни, які нині відбуваються у світі, безумовно, впливають на розвиток i функціонування мови як основного комунікаційного засобу на фоні усіх етнокультурних процесів. Мови різняться не тільки суспільними функціями, сферами вживання, авторитетом у своїй країні та за її межами, а й кількістю людей, що ними спілкуються. Інтенсивні та довготривалі контакти народів нерідко зумовлюють виникнення дво- та багатомовності.

Mema cmammi- розглянути поняття дво- та багатомовності як чинника соціально-політичного життя в Канаді, визначити причини виникнення та основні етапи розвитку багатомовності в Канаді.

Нині в науковій літературі наявні різні визначення як багатомовності, так i двомовності (білінгвізму). Термін «білінгвізм» запозичений із французької мови (bilinguisme), але в середині XX століття в лінгвістиці з'явився англійський термін (bilingualism), який у науковий обіг увів американський дослідник У. Вайнрайх він трактує білінгвізм як практику поперемінного користування мовами.

Дослідник Ж. Череднякова розуміє багатомовність (мультилінгвізм) у двох значеннях: по-перше, як здатність особистості використовувати кілька мов, подруге, як співіснування декількох мов у суспільстві в межах однієї країни [5].

На думку О. Першукової, багатомовність, або мультилінгвізм, виявляються на індивідуальному та суспільному рівнях. На індивідуальному рівні мультилінгвізм означає здатність особистості до спілкування кількома мовами, а саме: рідною, кількома іноземними, офіційною або державною мовою країни проживання, яка може відрізнятися від рідної мови, а також мовами, що функціонують на території країни. На суспільному рівні багатомовність - це співіснування різних мовних співтовариств на одному географічному просторі в умовах багатомовного міста чи багатомовної країни [3].

Ми дотримуємось дефініцій, запропонованих Е. Апельтауером: «Двомовність це здатність поперемінного використання двох мов», а за аналогією «багатомовність - це здатність поперемінного використання кількох (трьох i більше) мов» [2].

Найтиповішими умовами для виникнення білінгвізму вважають:

- виховання дитини в сім'ї, де батьки спілкуються різними мовами;

- проживання сім’і в іншомовному оточенні, що змушує дитину спілкуватися рідною мовою в родині і використовувати іншу мову в навчанні;

- організоване систематичне формування двомовності у процесі вивчення іноземної мови в школі [1].

Багатомовність у Канаді природна, зумовлена об'єктивними причинами. Етнічний склад населення та розмаїття його мовних практик визначили багатомовність цієї країни. Населення країни поділяється на англоканадців, рідною мовою яких $\epsilon$ англійська; франко-канадців, рідною мовою яких $\epsilon$ французька; алофонів, рідною мовою яких є будь-яка інша мова. Така мовна ситуація склалася через низку причин.

Формування багатомовного суспільства у Канаді має свої етапи, кожен 3 яких зумовлено історичними, політичними та суспільними причинами:

1. Етап освоєння та розподілу канадських земель (XVII-XVIII ст.).

У 1605 році в Канаді (Нова Франція) засновано перше постійне французьке поселення. Французи освоювали нові території протягом XVI-XVIII століть. У 1663 
році Нова Франція була офіційно оголошена володінням французького королівства, але вже у 1713 році Франція, ослаблена війною за іспанський спадок, поступається східною частиною Нової Франції, Акадією, на користь Англії.

Семирічна війна (1756-1763) сприяла ще більшому розширенню англійцями своїх володінь на території Нової Франції. Після підписання Паризького договору (1763), який закріпив остаточну втрату Францією своїх північноамериканських колоній, уся політична влада зосередилась у руках англомовного канадського суспільства, у той час як франко-канадці були відчужені від участі в управлінні державою.

Прагнучи затвердити свої привілеї в господарському й політичному житті колонії, англійці, незважаючи на те, що осіб англійського походження було на той час менше, ніж франко-канадців, домагалися переходу на англійську мову, проводячи вкрай жорстку мовну політику, спрямовану на форсоване витіснення французької мови та швидку асиміляцію їі носіїв [4].

2. Етап боротьби за виживання французької мови (XVIII - перша половина XX ст.).

Протягом усього часу співіснування франко-канадців та англоканадців франкомовне населення вело боротьбу за виживання рідної мови, що виявлялося у прагненні використовувати французьку мову в сім'і, богослужінні, освіті.

Починаючи з другої половини ХІХ століття, у Канаді розв'язуються проблеми, пов'язані 3 англійською і французькою мовами. Зокрема, уряд держави почав приділяти увагу розвитку офіційної двомовності у країні. Прийнято чимало актів, які визначали сфери дії англійської та французької мов. У 1867 році англійським парламентом прийнято Акт про Британську Північну Америку, який дозволяв використовувати французьку мову на офіційному рівні (у парламенті та судах Канади, а також у судах і легіслатурі провінції Квебек).

У 1927 році надписи на поштових марках зроблено обома офіційними мовами, а у 1934 році наказом парламенту Канади створене федеральне бюро перекладів. У 1936 році двомовними стають грошові купюри, а з 1959 року дебати в палаті общин почали проводитися одночасно англійською і французькою мовами. У $1963-$ 1970 рр. створюється королівська комісія з білінгвізму.

Незважаючи на такі заходи з боку уряду, у Канаді встановився білінгвізм, де білінгвами були виключно франко-канадці. Протягом першої половини XX століття французька мова залишалася мовою побутового спілкування, у той час як англійська - мовою адміністрації.

3. Етап становлення офіційної двомовності в Канаді (ІІ половина XX ст.).

Починаючи з 1960-х рр., у Канаді здійснюється державна політика білінгвізму, поштовхом до якої були події у Квебеку у 60-ті рp. XX століття. У 1968 році до парламенту будо подано Закон про офіційні мови (Official Language Act). Новий прем'єр-міністр Канади, франко-канадієць П'єр Еліот Трюдо, був ініціатором цього закону. Акт про офіційні мови, який встановлював рівність англійської і французької мов як в уряді, так і в суспільстві, схвалено парламентом у 1969 році. Основні положення закону такі:

- забезпечення рівного статусу англійської і французької мов;

- повага цих мов як офіційних мов країни;

- підтримка державними установами французької мови [8].

У 1977 році прийнято Закон № 101 «Хартія французької мови», яким офіційно визнано домінування французької мови над англійською у провінції Квебек, що 
дозволило квебекцям виражати свою національну ідентичність. Закон № 101 стосувався основних трьох напрямків: мова та економіка, мова та державне управління, мова та освіта. Конституцією країни 1980 року передбачалася офіційна рівність між французькою та англійською мовами на всій території Канади.

У 1988 році було прийнято Акт «Про збереження й посилення мультикультурної освіти в Канаді» («Act for the Preservation and Enhancement of Multiculturalism in Canada»). Акт 1988 року проголошував культурне різноманіття як базовий принцип канадського суспільства. Офіційно проголошувався курс на збереження й розвиток субкультур меншості, на рівність культур у соціальному культурному житті.

У 2003 році державний уряд Канади прийняв «План дій щодо офіційних мов», метою якого було збільшити кількість білінгвів серед молоді вдвічі. Сьогодні в Канаді на урядовому рівні реалізується Програма розвитку офіційних мов меншин (Development of Official Language Communities Program). Програма має заохочувати англо- та франкомовних меншин Канади до участі у всіх галузях суспільного життя. Програма обіцяє допомогти англо- та франкомовним меншинам отримати якісну освіту та доступ до різних послуг рідною мовою.

4. Етап глобалізації та міграції (кінець XX ст. - початок XXI ст.).

На сучасному етапі в розвитку багатомовності в Канаді велику роль відіграє імміграція. Специфіка географічного ландшафту Канади та демографічні особливості цієї країни протягом багаторічної історії ставали спонукальними мотивами залучення іммігрантів. Масове прибуття переселенців із різних країн i континентів посилює й урізноманітнює етнічні компоненти в багатокультурній палітрі сучасного канадського суспільства. Існує три основних категорії іммігрантів: економічні іммігранти, сімейні іммігранти та біженці.

Серед населення Канади англійську мову нині вважають рідною для себе майже $60 \%$ канадійців, французьку - 22\%. Для понад 5 млн. осіб рідною є одна 3 неофіційних мов (китайська, італійська, українська, німецька, пенджабська тощо). При цьому 98,5 \% населення володіє хоча б однією з федеральних офіційних мов англійською або французькою. Лише англійською володіє $67,5 \%$, лише французькою - 13,3\%, обома - 17,7 \% [6].

За останні роки, як зазначає Патріція Дафф, розмаїття неофіційних мов у Канаді зазнає змін. Так, у 2001 році населення Канади складало приблизно 30 мільйонів, серед яких 58\% визнали рідною мовою англійську, 23\% - французьку мову, решта вважає рідними інші європейські і неєвропейські мови. За статистикою 2001 року до п'яти найпопулярніших неофіційних мов відносять китайську, італійську, німецьку, польську, іспанську [7].

Отже, багатомовність у Канаді природна, визначена етнічним складом населення та розмаїттям його мовних практик. Поширення багатомовності продиктовано прагненням канадійців долучитися до своїх субкультурних ідеалів, для чого необхідно належно володіти рідною мовою. Етнічні меншини прагнуть домагатися цивільних прав, що неможливо без засвоєння домінуючих мов. Федеральний уряд надає необхідну фінансову підтримку під час організації відповідного білінгвального навчання, що набуло поширення у країні.

\section{Література}

1. Бондарчук Т. Використання психологічних особливостей білінгвізму в процесі організації двомовного навчання / Т. Бондарчук // Вісник Львів. ун-ту ім. Івана Франка : серія педагогічна. - 2008. - Вип. 23. - С. 63-73. 2. Гаманюк В. А. 
Іншомовна освіта Німеччини у контексті загальносвропейських інтеграційних процесів: теорія i практика: [монографія]/ В. А. Гаманюк. - Кривий Ріг: Видавничий дім, 2012. - 375 с. 3. Першукова О. О. Багатомовна освіта пріоритетний напрям розвитку європейської мовної галузі / О.О.Першукова // Порівняльно-педагогічні студії. $\quad$ № 3-4. - 2010. - $\quad$ С. 12-16. 4. Тишков В. А. История Канады / В. А. Тишков, Л. В. Кошелев // М: Мысль, 1982. - 268 с. 5. Чернякова Ж. Мультилінгвізм як проблема порівняльнопедагогічних досліджень / Ж. Чернякова // Наукові записки НДУ ім. М. Гоголя: Психолого-педагогічні науки. - 2011. - № 1. - С. 36-39. 6. Яковлева О. Моделі багатомовності - світовий досвід: Канада, Південно-Африканська республіка, Індія, Сінгапур [Електронний ресурс] / О. Яковлева. - Режим доступу: http: //dcsummit.info/temy/nacionalnaja-identichnost/2280-modeli-bagatomovnosti-svitovijdosvid-1.html 7. Duff Patricia A. Multilingualism in Canadian schools: Myths, realities and possibilities / Patricia A. Duff // Canadian Journal of Applied Linguistics. - Vol. 10, Issue 2. - 2007. - P. 149-163. 8. Official Languages Act [Електронний pecypc]. Режим доступу: http://www.ocol-clo.gc.ca/html/act_loi_e.php. 